\title{
Effect of combined siRNA of HCV E2 gene and $\mathrm{HCV}$ receptors against $\mathrm{HCV}$
}

\author{
Shah Jahan ${ }^{1 * \dagger}$, Saba Khaliq ${ }^{1 *+}$, Baila Samreen ${ }^{1 \dagger}$, Bushra ljaz ${ }^{1}$, Mahwish Khan¹, Waqar Ahmad ${ }^{1}$, Usman Alli A Ashfaq ${ }^{2}$ \\ and Sajida Hassan ${ }^{1}$
}

\begin{abstract}
Background/Aim: Hepatitis C virus (HCV) is a major threat as almost 3\% of the world's population (350 million individual) and $10 \%$ of the Pakistani population is chronically infected with this virus. RNA interference (RNAi), a sequence-specific degradation process of RNA, has potential to be used as a powerful alternative molecular therapeutic approach in spite of the current therapy of interferon- $\alpha$ and ribavirin against HCV which has limited efficiency. HCV structural gene E2 is mainly involved in viral cell entry via attachment with the host cell surface receptors i.e., CD81 tetraspanin, low density lipoprotein receptor (LDLR), scavenger receptor class B type 1 (SR-B1), and Claudin1 (CLDN1). Considering the importance of HCV E2 gene and cellular receptors in virus infection and silencing effects of RNAi, the current study was designed to target the cellular and viral factors as new therapeutic options in limiting HCV infection.
\end{abstract}

Results: In this study the potential of siRNAs to inhibit HCV-3a replication in serum-infected Huh-7 cells was investigated by combined treatment of siRNAs against the HCV E2 gene and HCV cellular receptors (CD81 and LDLR), which resulted in a significant decrease in HCV viral copy number.

Conclusion: From the current study it is concluded that the combined RNAi-mediated silencing of HCV E2 and HCV receptors is important for the development of effective siRNA-based therapeutic option against HCV-3a.

Keywords: HCV, siRNA, HCV receptors, HCV envelope genes and viral titer

\section{Introduction}

$\mathrm{HCV}$ infection is a major health problem with nearly $10 \%$ chronically infected population in Pakistan and 350 million people worldwide [1,2]. About $75 \%$ of patients achieve no therapeutic benefit from the present combination therapy with pegylated interferon $\alpha$ (PEG-IFN- $\alpha$ ) and ribavirin mainly depending upon $\mathrm{HCV}$ genotype, whereas in $40-60 \%$ patients chronic infection is mainly associated with liver cirrhosis and steatosis leading to hepatocellular carcinoma (HCC) [3-5]. In Pakistan the major HCV genotype is $3 \mathrm{a}$ followed by $3 \mathrm{~b}$ and $1 \mathrm{a}$, with a strong correlation between chronic HCV infection and HCC in Pakistan associated with genotype 3a [6,7]. There is a desperate need to develop more efficient and

\footnotetext{
* Correspondence: captainmalik@hotmail.com; sabahat711@yahoo.com † Contributed equally

${ }^{1}$ Applied and Functional Genomics Lab, Centre of Excellence in Molecular Biology, University of the Punjab, 87 West Canal Bank Road Thokar Niaz Baig, Lahore, Pakistan

Full list of author information is available at the end of the article
}

better therapeutic alternative for treatment of $\mathrm{HCV}$ infections.

Due to the absence of suitable animal model and competent in vitro cell culture system the mechanism of $\mathrm{HCV}$ cell entry was unrevealed after a long time. Recently, different groups have studied HCV replication in serum infected liver cell lines which mimics the naturally occurring $\mathrm{HCV}$ virions biology and kinetics of $\mathrm{HCV}$ infection in humans liver cells [8-11]. HCV envelop glycoproteins E1 and E2 are involved in HCV entry, fusion and defense against neutralization by envelop-specific host antibodies [12-18]. E2 glycoprotein works as a key component in interaction between the virus and its major cellular receptors i.e., CD81, SR-BI and CLDN1 [15-17]. CD81 is a main $\mathrm{HCV}$ cell surface receptor, whereas additional role is played by the scavenger receptor class B type I (SRBI) and the low-density-lipoproteins receptor (LDLR) [19-22]. LDLR is potentially involved in the uptake of lipoproteinassociated $\mathrm{HCV}$ into hepatocytes as serum fraction
C Biomed Central

(C) 2011 Jahan et al; licensee BioMed Central Ltd. This is an Open Access article distributed under the terms of the Creative Commons Attribution License (http://creativecommons.org/licenses/by/2.0), which permits unrestricted use, distribution, and reproduction in any medium, provided the original work is properly cited. 
composed of HCV with LDL, or very low-density lipoprotein (VLDL), which are involved in binding to the LDL receptor as a possible mechanism of $\mathrm{HCV}$ cell entry [23-25]. Hence, HCV envelope glycoprotein and cellular receptors is good target for the development of antiviral molecules that could block HCV entry.

Being a RNA virus HCV is highly susceptible to RNA interference (RNAi) induced by small interfering RNA (siRNA), which is a sequence specific gene silencing mechanism [26-28]. siRNAs can be used as a potential therapeutic agent against HCV because HCV replication takes place in the cytoplasm of liver cells without integration into the host genome. siRNA directed against HCV genotype 1a and $1 \mathrm{~b}$ has been shown to effectively block the replication of viral replicons in Huh-7-derived cell lines [29-35]. In our previous study, the development of siRNA targeting envelope proteins of the local $\mathrm{HCV}-3 \mathrm{a}$ genotype showed that these genes are crucial for viral entry providing better choice for developing a rational antiviral strategy against HCV [36]. Several investigators have reported the inhibition of HCV RNA by targeting structural and non structural genes of $\mathrm{HCV}$ and cellular genes by using siRNAs in combination [33,36-38]. In this report, we investigated the effect of siRNA induced silencing of receptor genes and HCV E2 on viral load of HCV followed by a combined effect which showed a significantly decreased viral RNA.

\section{Results}

Cellular genes CD81 and LDLR are functionally involved in $\mathrm{HCV}$ entry. Our previous results also show that sequence specific siRNAs against each receptor significantly inhibit the expression of their respective genes of receptors CD81, LDLR, SRBI and CLDN1 (data submitted for publication). Keeping all these in view, we used in-vitro transcribed siRNA against HCV E2 gene and cellular receptors CD81and LDLR and observed the effect of silencing of these receptors on viral titer. Previously, we have successfully inhibited $\mathrm{HCV}$ by E2 siRNAs [36], from that study we selected the best one for this study. The effect on viral titer was analyzed by silencing each receptor and E2 gene individually and then in combination of siRNAs against two receptors and E2 gene simultaneously. To evaluate the role of $\mathrm{HCV}$ E2 gene and $\mathrm{HCV}$ receptors in $\mathrm{HCV}$ infection and HCV pathogenesis, Huh-7 cells were infected with HCV-3a serum with or without siRNAs against $\mathrm{HCV}$ receptors CD81, LDLR and HCV E2-3a gene for 48hrs and viral loads were quantified by Real Time PCR. Results showed a decrease of $62 \%, 45 \%$, with $\mathrm{HCV}$ receptor siRNA CD-81, LDL, $60 \%$, and $72 \%$ with $\mathrm{HCV}$ E2 siRNA, (E2si873), respectively in viral load. A significant suppression of HCV RNA (84\% and 78\%) was observed with the combination of both siRNAs against
HCV E2 gene, E2 siRNA (E2si873) and HCV receptor genes CD81(siCD81-B), LDLR (siLDLR) (Figure 1).

Furthermore, the effect on protein expression inhibition of HCV structural gene E2, receptor genes CD81 and LDLR on the expression of viral protein were determine by western blot analysis using specific antibodies. Huh-7 cell lysates infected with HCV serum of genotype $3 \mathrm{a}$ with or without siRNAs (100nM each) against HCV receptors CD81, LDLR and HCV E2-3a gene for 48hrs were separated through SDS PAGE and treated with specific antibodies of each gene. Results indicate the significant inhibition of protein expression of CD81 and E2 $3 \mathrm{a}$, when combination of siRNA (E2si873 + siCD81-B) were used as compare to individual siRNA against CD81 and HCV E2 (Figure 2A). These results show the reduce total cellular viral protein expression due to the low expression of $\mathrm{HCV}$ envelop protein as well as CD81 receptor protein simultaneously. Similarly, western blotting results indicate the significant inhibition of expression of LDLR and E2 3a, when combination of siRNA (E2si873 +siLDLR) were used as compare to individual siRNA against LDLR and HCV E2 (Figure 2B), which also show the reduce total cellular viral protein expression due to the low expression of HCV envelop protein as well as LDLR receptor protein simultaneously.

\section{Discussion}

HCV entry into hepatocytes, a multistep process mediated by $\mathrm{HCV}$ envelop glycoprotein E1 and E2 and several cell surface receptors, is first step of virus life

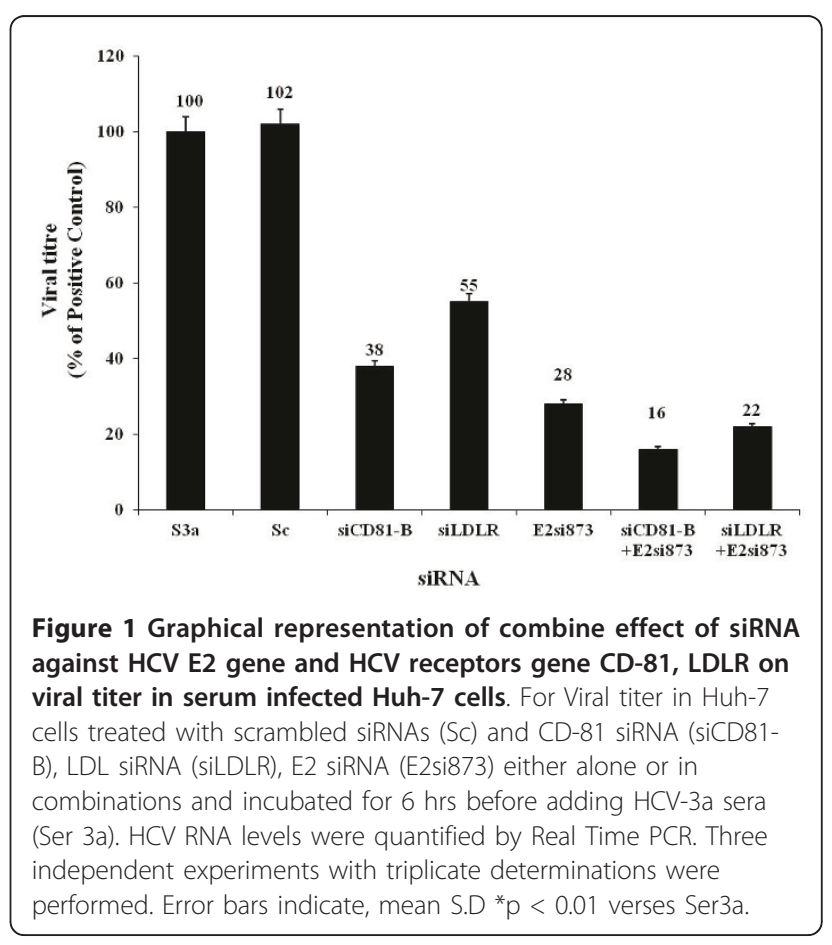




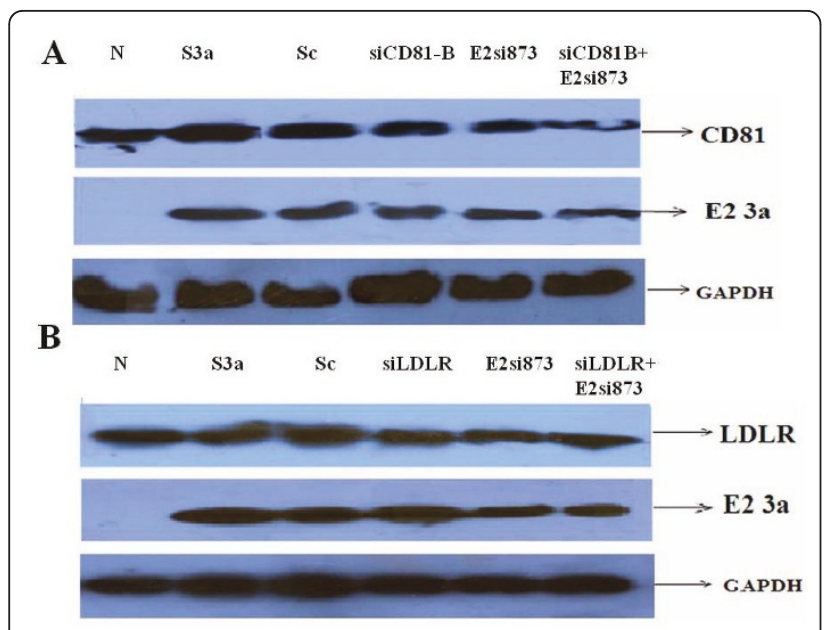

Figure 2 Protein expression analysis of HCV E2 gene and HCV receptors genes by using siRNA alone and in combination against HCV gene E2 and HCV receptor genes CD81, LDLR. Protein isolated from Huh-7 cells treated with single and combination of siRNA against HCV E2 gene and receptor CD81 and LDLR genes and incubated for 6 hrs before adding HCV-3a sera (Ser 3a) for $48 \mathrm{hrs}$. Protein levels were quantified by western blot analysis using specific antibodies of CD81, LDLR, E2 and GAPDH. A) Silencing of CD81 gene and HCV 3a E2 gene alone and in combination using specific antibodies showing reduction at protein expression level. B) Silencing of LDLR gene and HCV 3a E2 gene alone and in combination, using specific antibodies showing reduction at protein expression level. Protein levels for GAPDH gene are also shown as internal control and scramble siRNA (Sc) as siRNA control.

cycle that results in productive viral infection, providing major targets for immunopreventive and therapeutic strategies [39-41]. The cell surface receptors mainly include tetraspanin protein CD81, SR-BI, LDLR and CLDN1 a tight junction protein [17,20-22,42]. HCV envelop protein E2 posses' glycosylation sites which interact directly with these cell surface receptors. As in our previous study, here too we utilized serum infected Huh-7 cell culture model to evaluate the effect of siRNA separately and in combination against $\mathrm{HCV}$ structural gene and receptor genes on viral entry by quantifying the viral titer in siRNA-treated and nontreated serum-infected Huh-7 cells.

RNAi is an exciting new therapeutic technology proposed to be used in treatment of viral diseases. $\mathrm{HCV}$ is an attractive target for RNAi therapy as its genome is a (+) sense single stranded RNA that functions as both the viral messenger RNA and template for RNA replication via negative strand intermediate. Previously it has been reported that cellular genes functionally involved in HCV entry like CD81, LDLR, SR-BI and CLDN1 also serve as potential targets for RNAi. Several reports showed potent RNAi against HCV genes and cellular receptors activity to reduce the $\mathrm{HCV}$ infection in which expression of $\mathrm{HCV}$ was distinctly inhibit $\mathrm{HCV}$ serum infection (30\%-90\%) [11,36,42-45]. In our current project, we utilized siRNAs to silence the expression of $\mathrm{HCV}$ cellular receptors and E2 gene to block the HCV entry in serum derived HCV infected Huh-7 cell culture model and analyze its effect on viral load. HCV infection pathway employs enhancement in expression of cell surface receptors that may facilitates to increase viral load. In account of these, we knock down the expression of host cell surface HCV receptors by using siRNA to block HCV entry, against each receptor gene separately and in combination of siRNA against two receptors gene in Huh-7 cells which were further infected with $\mathrm{HCV}$ serum of genotype $3 \mathrm{a}$ and observed the viral titer by detection of 5'UTR of viral copies by Real Time PCR in cells from $3^{\text {rd }}$ day post infection. Our results indicate significant decrease in HCV viral load by $67 \%$ and $58 \%$ due to the silencing of $\mathrm{HCV}$ receptor CD81 (33 fold) and LDLR (42 fold) respectively when compared to control (S3a), (Figure 1). Since, LDLR is important for HCV-E1-pseudotype infectivity, whereas CD81 determines the infectivity of HCV-E2-pseudotype virus, the silencing effect of siRNAs against selected HCV infection host cellular proteins has been evaluated to reduce viral titer significantly. Thus use of combinations of siRNAs against both the virus and host genes involve in $\mathrm{HCV}$ infection are likely to be a potent approach in the treatment of chronic hepatitis $\mathrm{C}$ due to their additive HCV RNA inhibition effects. Moreover, different studies exhibit the feasibility of targeting host cellular factors involved in infection, as they are not prone to mutations, as potential targets for siRNA therapy. Henry and colleagues [46] targeted the IRES, NS5B, and host cell receptor CD81 by triple shRNA expression vector which concurrently reduced the HCV replication, CD81 expression, and E2 binding. Targeting multiple sites of the $\mathrm{HCV}$ genome and host factors involved in $\mathrm{HCV}$ infection are a realistic and valid approach aimed at preventing the virus from developing resistance.

In correspondence to the latest reports, we also investigated the down regulation of viral titer by silencing the expressions of HCV envelop gene alone using HCV E2 specific siRNA (E2si873) and in combination with the silencing of CD81 or LDLR gene expression using siCD81-B, siLDLR in Huh-7 cells which were further infected HCV 3a serum. Our findings showed a significant decrease in HCV viral titer up to $67 \%$ and $58 \%$, with siCD81-B, siLDLR and $72 \%$ with HCV E2 siRNA (E2si873), respectively in the Huh-7 cells. A significant suppression of HCV RNA ( $84 \%$ and $78 \%$ ) was observed with the combination of both siRNAs against HCV E2 gene, E2 siRNA (E2si873), and CD81, LDLR siRNAs (Figure 1). Likewise, cell lysates from HCV serum infected Huh-7 cells were examined by western blot 
analysis using CD81, LDLR and HCV-E2 specific antibodies. Our results showed considerable decreased in the protein levels of CD81, LDLR and HCV-E2 in transiently transfected siCD81-B, siLDLR and E2si873 siRNAs, whereas combination of siCD81-B + E2si873 and E2si873 + siLDLR resulted in a more significant decrease of CD81, LDLR protein expression that ultimately reduced the protein level of HCV-E2 which depicts the reduced entry of $\mathrm{HCV}$, hence lessen the $\mathrm{HCV}$ infection (Figure 2).

In summary, our data showed that CD81 and LDL specific siRNAs not only reduced their gene expression respectively but also reduced viral titer in siRNA treated cells confirming their role in $\mathrm{HCV}$ infection; combination of these siRNA (siCD81-B, siLDLR) with E2 effective siRNA (E2si873) showed dramatic reduction of $\mathrm{HCV}$ entry. Use of siRNA to inhibit the HCV E2 protein or $\mathrm{HCV}$ receptor protein expression alone or in combination could be helpful in reduction of HCV entry. In addition, we propose the use of combination siRNAs against HCV gene with host genes which could inhibit $\mathrm{HCV}$ entry better than separately used siRNA.

\section{Materials and Methods}

\section{Source of samples}

The local HCV-3a patient's serum samples used in this investigation were obtained from the CAMB (Center for Applied Molecular Biology) diagnostic laboratory, Lahore, Pakistan after quantification and genotype determination. Serum samples were stored at $-80^{\circ} \mathrm{C}$ prior to RNA extraction for cloning and viral inoculation experiments. Patient's written consent and approval for this study was obtained from institutional ethics committee.

\section{Designing and synthesis of siRNA}

Designing and synthesis of siRNA were done as we have described earlier [36]. siRNA oligonucleotides were designed to express RNAi mechanism against host $\mathrm{HCV}$ receptors (LDLR and CD81) and E2 region of HCV-3a genome using the Ambion's siRNA design tool http:// www.ambion.com/techlib/misc/siRNA_finder.html after sequencing of local HCV-3a patient's serum samples (Table 1). The designed siRNAs (cellular genes HCV receptors, HCV-3a E2 and control Scrambled) were synthesized using Silencer siRNA construction kit according to the manufacturer's instruction (Ambion, USA).

\section{Viral inoculation and co-transfection with siRNA}

Huh-7 cell line was kindly provided by Dr. Zafar Nawaz (University of Miami, USA) and maintained in Dulbecco's modified eagle medium (DMEM) supplemented with $100 \mu \mathrm{g} / \mathrm{ml}$ penicillin; streptomycin and $10 \%$ fetal bovine serum referred as complete medium (Sigma
Table 1

\begin{tabular}{ll}
\hline Name & Sequences \\
\hline Scramble-antisense & AACCTGCATACGCGACTCGACCCTGTCTC \\
Scramble-sense & AAGTCGAGTCGCGTATGCAGGCCTGTCTC \\
CD81-B antisense & AAGATGCCTACATAGAAGGTGCCTGTCTC \\
CD81-B sense & AACACCTTCTATGTAGGCATCCCTGTCTC \\
LDL antisense & AAATGCATCTCCTACAAGTGGCCTGTCTC \\
LDL sense & AACCACTTGTAGGAGATGCATCCTGTCTC \\
E2si873-antisense & AACAACTGAGCTGCCATACTCCTGTCTC \\
E2si873-sense & AAAGTATGGCAAGCTCAGTTGCCTGTCTC \\
\hline
\end{tabular}

Aldrich, USA) at $37^{\circ} \mathrm{C}$ with $5 \% \mathrm{CO}_{2}$. The medium was renewed every 3 day and passaged every 4-5 days. Huh7 cell line was used to establish the in vitro replication of HCV genotype 3a. A similar protocol was used for viral inoculation as described by earlier $[36,45]$. For these experiments high viral titer $>1 \times 10^{8} \mathrm{IU} / \mathrm{ml}$ containing serum from $\mathrm{HCV}-3$ a patient was used as principle inoculum. Huh-7 cells were maintained in 6-well culture plates to semi-confluence, washed twice with serum-free medium then inoculated with $500 \mu \mathrm{l}(5 \times$ $10^{7} \mathrm{IU} /$ well) viral load of HCV-3a sera and $500 \mu \mathrm{l}$ serum free media. Cells were maintained overnight at $37^{\circ} \mathrm{C}$ in $5 \% \mathrm{CO}_{2}$. Next day, the adherent cells were washed three times with $1 \times \mathrm{PBS}$, complete medium was added and incubation was continued for $48 \mathrm{hrs}$. Cells were harvested and assessed for the presence of viral RNA quantitatively by Real Time PCR. To analyze the effect of siRNA on HCV infection, serum infected Huh-7 cells were seeded after three days of infection in 24-well plates and grown to $80 \%$ confluence with $2 \mathrm{ml}$ medium. The cells were transfected with or without $40 \mu \mathrm{M} /$ well cellular receptors CD81, LDL-R and E2 siRNAs alone or in combination using Lipofectamine ${ }^{\mathrm{TM}} 2000$ (Invitrogen Life technologies, CA) according to the manufacturer's protocol.

\section{Viral load quantification}

Cells were harvested for viral load determination using Gentra RNA isolation kit (Gentra System Pennsylvania, USA) according to the manufacturer's instructions. For viral quantification Sacace HCV quantitative analysis kit (Sacace Biotechnologies Caserta, Italy) was used. Briefly, $10 \mu \mathrm{l}$ of extracted viral RNA was mixed with an internal control provided by Sacace HCV Real TM Quant kit and subjected to viral quantification using Real Time PCR SmartCycler II system (Cepheid Sunnyvale, USA).

\section{Total RNA isolation and gene expression analysis}

Total RNA from HCV serum infected and non-infected cells was isolated using TRIzol reagent (Invitrogen life technologies, CA), $24 \mathrm{hrs}$ and $48 \mathrm{hrs}$ post-transfection. To analyze the effect of siRNA on envelope gene 
expression, cDNA was synthesized with $1 \mu \mathrm{g}$ of total RNA using Superscript III cDNA synthesis kit (Invitrogen life technologies, $\mathrm{CA}$ ) and semi-quantitative RTPCR was done using primers of HCV receptors, E2 genes and GAPDH as control. Quantitative Real Time PCR was carried out using Real Time ABI 7500 system (Applied Biosystems Inc, USA) with SYBR Green mix (Fermentas International Inc, Canada) as we have described earlier [36]. The relative gene expression analysis was carried out by the SDS 3.1 software (Applied Biosystems Inc, USA). Each individual experiment was performed in triplicate.

\section{Western blotting}

To determine the effect of siRNAs on protein expression levels $\mathrm{HCV}$ receptors CD81 and LDL-R and E2, in HCV serum infected cells, cells were lysed using ProteoJET mammalian cell lysis reagent (Fermentas, Canada). Equal amounts of total proteins were subjected to electrophoresis on $12 \%$ SDS-PAGE and electrophoretically transferred to a nitrocellulose membrane according to the manufacturer's protocol (Bio-Rad, CA). After blocking non-specific binding sites with $5 \%$ skimmed milk, blots were incubated with primary monoclonal antibodies specific to HCV cellular receptors like CD81 and LDL-R, HCV E2 and GAPDH genes (Santa Cruz Biotechnology Inc, USA) and secondary Horseradish peroxidase-conjugated anti-goat anti-mouse antibody (Sigma Aldrich, USA). The protein expressions were evaluated using chemiluminescence's detection kit (Sigma Aldrich, USA).

\section{Statistical analysis}

All statistical analysis was done using SPSS software (version 16.0, SPSS Inc). Data are presented as mean \pm SD. Numerical data were analyzed using student's t-test and ANOVA. P value $<0.05$ was considered statistically significant.

\section{List of abbreviations}

E1, E2: Envelop proteins 1, 2, HCC: Hepatocellular carcinoma, HCV: Hepatitis C virus, CD81: Cluster of differentiation 81, SR-Bl: Scavenger Receptor Class B Type I, LDL-R: Low-Density Lipoprotein Receptor, CLDN 1: Claudin 1, PEGINF-a: pegylated interferon alpha, RNAi: RNA interference, siRNAs: small interfering RNAs.

\section{Acknowledgements}

Financial support by Higher Education Commission and all facilities provided by $C E M B / C A M B$ are highly acknowledged.

\section{Author details}

${ }^{1}$ Applied and Functional Genomics Lab, Centre of Excellence in Molecular Biology, University of the Punjab, 87 West Canal Bank Road Thokar Niaz Baig, Lahore, Pakistan. ${ }^{2}$ Division of Molecular Medicine, Centre of Excellence in Molecular Biology, University of the Punjab, Lahore, Pakistan.

\section{Authors' contributions}

SJ, SK and BS contributed equally to this work, conceive the idea and performed all the lab work. MH and UAA helped SJ and SK in lab work and literature review. BI and WA helped SJ and SK in data analysis. SK and SJ critically reviewed and finalized the manuscript. $\mathrm{SH}$ provided all facilitates to complete this work. All authors read and approved the final manuscript.

\section{Authors' information}

Shah Jahan (PhD Molecular Biology), Saba Khaliq (PhD Molecular Biology), Bailla Samreen (M.Phil Molecular Biology), Mahwish Khan (M.Phil Molecular Biolohgy) and Usman Ali Ashfaq (PhD Molecular Biology) are research scholars at CEMB. Bushra ljaz (M.Phil Molecular Biology) and Wagar Ahmad (M.Phil Chemistry) are research officers at CEMB whereas Sajida Hassan (PhD Molecular Biology) principle investigator at CEMB, University of the Punjab, Lahore.

\section{Competing interests}

The authors declare that they have no competing interests.

Received: 16 May 2011 Accepted: 10 June 2011 Published: 10 June 2011

\section{References}

1. Giannini C, Brechot C: Hepatitis C virus biology. Cell Death Differ 2003, 10(Suppl 1):S27-S38.

2. Raja NS, Janjua KA: Epidemiology of hepatitis $C$ virus infection in Pakistan. J Microbiol Immunol Infect 2008, 41:4-8.

3. Afdhal NH: The natural history of hepatitis C. Semin Liver Dis 2004 24(Suppl 2):3-8.

4. Manns MP, McHutchison JG, Gordon SC, Rustgi VK, Shiffman M, Reindollar R, Goodman ZD, Koury K, Ling M, Albrecht JK: Peginterferon alfa-2b plus ribavirin compared with interferon alfa- $2 b$ plus ribavirin for initial treatment of chronic hepatitis C: a randomised trial. Lancet 2001, 358:958-965.

5. Mengshol JA, Golden-Mason L, Rosen HR: Mechanisms of Disease: HCV-induced liver injury. Nat Clin Pract Gastroenterol Hepatol 2007, 4:622-634.

6. Idrees $M$, Riazuddin S: Frequency distribution of hepatitis $C$ virus genotypes in different geographical regions of Pakistan and their possible routes of transmission. BMC Infect Dis 2008, 8:69.

7. Idrees M, Rafique S, Rehman I, Akbar H, Yousaf MZ, Butt S, Awan Z, Manzoor S, Akram M, Aftab M, Khubaib B, Riazuddin S: Hepatitis C virus genotype 3a infection and hepatocellular carcinoma: Pakistan experience. World J Gastroenterol 2009, 15:5080-5085.

8. Buck M: Direct infection and replication of naturally occurring hepatitis $C$ virus genotypes 1, 2, 3 and 4 in normal human hepatocyte cultures. PLoS One 2008, 3:e2660.

9. el-Awady MK, Tabll AA, el-Abd YS, Bahgat MM, Shoeb HA, Youssef SS, Bader el-Din NG, Redwan e, el-Demellawy M, Omran MH, el-Garf WT, Goueli SA: HepG2 cells support viral replication and gene expression of hepatitis $C$ virus genotype 4 in vitro. World J Gastroenterol 2006, 12:4836-4842.

10. Lazaro CA, Chang M, Tang W, Campbell J, Sullivan DG, Gretch DR, Corey L, Coombs RW, Fausto N: Hepatitis C virus replication in transfected and serum-infected cultured human fetal hepatocytes. Am J Pathol 2007, 170:478-489.

11. Molina S, Castet V, Pichard-Garcia L, Wychowski C, Meurs E, Pascussi JM, Sureau C, Fabre JM, Sacunha A, Larrey D, Dubuisson J, Coste J, McKeating J, Maurel P, Fournier-Wirth C: Serum-derived hepatitis $C$ virus infection of primary human hepatocytes is tetraspanin CD81 dependent. J Virol 2008, 82:569-574.

12. Bartosch B, Vitelli A, Granier C, Goujon C, Dubuisson J, Pascale S, Scarselli E, Cortese R, Nicosia A, Cosset FL: Cell entry of hepatitis $C$ virus requires a set of co-receptors that include the CD81 tetraspanin and the SR-B1 scavenger receptor. J Biol Chem 2003, 278:41624-41630.

13. Bartosch B, Dubuisson J, Cosset FL: Infectious hepatitis C virus pseudoparticles containing functional E1-E2 envelope protein complexes. J Exp Med 2003, 197:633-642.

14. Drummer HE, Maerz A, Poumbourios P: Cell surface expression of functional hepatitis C virus E1 and E2 glycoproteins. FEBS Lett 2003, 546:385-390.

15. Goffard A, Callens N, Bartosch B, Wychowski C, Cosset FL, Montpellier C, Dubuisson J: Role of $\mathrm{N}$-linked glycans in the functions of hepatitis $\mathrm{C}$ virus envelope glycoproteins. J Virol 2005, 79:8400-8409.

16. Helle F, Goffard A, Morel V, Duverlie G, McKeating J, Keck ZY, Foung S, Penin F, Dubuisson J, Voisset C: The neutralizing activity of anti-hepatitis 
C virus antibodies is modulated by specific glycans on the E2 envelope protein. J Virol 2007, 81:8101-8111.

17. Helle F, Dubuisson J: Hepatitis C virus entry into host cells. Cell Mol Life Sci 2008, 65:100-112.

18. Nielsen SU, Bassendine MF, Burt AD, Bevitt DJ, Toms GL: Characterization of the genome and structural proteins of hepatitis $C$ virus resolved from infected human liver. J Gen Virol 2004, 85:1497-1507.

19. Flint M, Maidens C, Loomis-Price LD, Shotton C, Dubuisson J, Monk P, Higginbottom A, Levy S, McKeating JA: Characterization of hepatitis C virus E2 glycoprotein interaction with a putative cellular receptor, CD81. J Virol 1999, 73:6235-6244.

20. Monazahian M, Bohme I, Bonk S, Koch A, Scholz C, Grethe S, Thomssen R: Low density lipoprotein receptor as a candidate receptor for hepatitis $C$ virus. J Med Virol 1999, 57:223-229.

21. Pileri P, Uematsu Y, Campagnoli S, Galli G, Falugi F, Petracca R, Weiner AJ, Houghton M, Rosa D, Grandi G, Abrignani S: Binding of hepatitis C virus to CD81. Science 1998, 282:938-941.

22. Scarselli E, Ansuini $H$, Cerino R, Roccasecca RM, Acali S, Filocamo G, Traboni C, Nicosia A, Cortese R, Vitelli A: The human scavenger receptor class $B$ type I is a novel candidate receptor for the hepatitis $C$ virus. EMBO J 2002, 21:5017-5025.

23. Agnello V, Abel G, Elfahal M, Knight GB, Zhang QX: Hepatitis C virus and other flaviviridae viruses enter cells via low density lipoprotein receptor. Proc Natl Acad Sci USA 1999, 96:12766-12771.

24. Lavillette D, Tarr AW, Voisset C, Donot P, Bartosch B, Bain C, Patel AH, Dubuisson J, Ball JK, Cosset FL: Characterization of host-range and cell entry properties of the major genotypes and subtypes of hepatitis $C$ virus. Hepatology 2005, 41:265-274.

25. Wunschmann S, Muller HM, Stipp CS, Hemler ME, Stapleton JT: In vitro interaction between hepatitis $\mathrm{C}$ virus (HCV) envelope glycoprotein E2 and serum lipoproteins (LPs) results in enhanced cellular binding of both HCV E2 and LPs. J Infect Dis 2006, 194:1058-1067.

26. Hannon GJ: RNA interference. Nature 2002, 418:244-251.

27. Sharp PA: RNA interference-2001. Genes Dev 2001, 15:485-490

28. Khaliq S, Khaliq SA, Zahur M, ljaz B, Jahan S, Ansar M, Riazuddin S, Hassan S: RNAi as a new therapeutic strategy against HCV. Biotechnol Adv 2010, 28:27-34.

29. Kanda T, Steele R, Ray R, Ray RB: Small interfering RNA targeted to hepatitis $C$ virus $5^{\prime}$ nontranslated region exerts potent antiviral effect. $J$ Virol 2007, 81:669-676.

30. Kapadia SB, Brideau-Andersen A, Chisari FV: Interference of hepatitis C virus RNA replication by short interfering RNAs. Proc Natl Acad Sci USA 2003, 100:2014-2018

31. Liu M, Ding H, Zhao P, Qin ZL, Gao J, Cao MM, Luan J, Wu WB, Qi ZT: RNA interference effectively inhibits mRNA accumulation and protein expression of hepatitis C virus core and E2 genes in human cells. Biosci Biotechnol Biochem 2006, 70:2049-2055.

32. Prabhu R, Vittal P, Yin Q, Flemington E, Garry R, Robichaux WH, Dash S: Small interfering RNA effectively inhibits protein expression and negative strand RNA synthesis from a full-length hepatitis $C$ virus clone. J Med Virol 2005, 76:511-519.

33. Randall G, Grakoui A, Rice CM: Clearance of replicating hepatitis C virus replicon RNAs in cell culture by small interfering RNAs. Proc Natl Acad Sci USA 2003, 100:235-240.

34. Seo MY, Abrignani S, Houghton M, Han JH: Small interfering RNAmediated inhibition of hepatitis $C$ virus replication in the human hepatoma cell line Huh-7. J Virol 2003, 77:810-812.

35. Wilson JA, Jayasena S, Khvorova A, Sabatinos S, Rodrigue-Gervais IG, Arya S, Sarangi F, Harris-Brandts M, Beaulieu S, Richardson CD: RNA interference blocks gene expression and RNA synthesis from hepatitis $C$ replicons propagated in human liver cells. Proc Natl Acad Sci USA 2003, 100:2783-2788

36. Khaliq S, Jahan S, ljaz B, Ahmad W, Asad S, Hassan S: Inhibition of hepatitis C virus genotype 3 a by siRNAs targeting envelope genes. Arch Virol 2011, 156:433-442.

37. Henry SD, van der WP, Metselaar HJ, Tilanus HW, Scholte BJ, van der Laan L: Simultaneous targeting of HCV replication and viral binding with a single lentiviral vector containing multiple RNA interference expression cassettes. Mol Ther 2006, 14:485-493.

38. Korf M, Jarczak D, Beger C, Manns MP, Kruger M: Inhibition of hepatitis C virus translation and subgenomic replication by siRNAs directed against highly conserved HCV sequence and cellular HCV cofactors. J Hepatol 2005, 43:225-234.

39. Liu S, Yang W, Shen L, Turner JR, Coyne CB, Wang T: Tight junction proteins claudin-1 and occludin control hepatitis $C$ virus entry and are downregulated during infection to prevent superinfection. J Virol 2009, 83:2011-2014.

40. Timpe JM, McKeating JA: Hepatitis $C$ virus entry: possible targets for therapy. Gut 2008, 57:1728-1737.

41. Zeisel MB, Koutsoudakis G, Schnober EK, Haberstroh A, Blum HE, Cosset FL, Wakita T, Jaeck D, Doffoel M, Royer C, Soulier E, Schvoerer E, Schuster C, Stoll-Keller F, Bartenschlager R, Pietschmann T, Barth H, Baumert TF: Scavenger receptor class B type I is a key host factor for hepatitis $C$ virus infection required for an entry step closely linked to CD81. Hepatology 2007, 46:1722-1731.

42. Evans MJ, Von HT, Tscherne DM, Syder AJ, Panis M, Wolk B, Hatziioannou T, McKeating JA, Bieniasz PD, Rice CM: Claudin-1 is a hepatitis C virus COreceptor required for a late step in entry. Nature 2007, 446:801-805.

43. Zhang J, Randall G, Higginbottom A, Monk P, Rice CM, McKeating JA: CD81 is required for hepatitis C virus glycoprotein-mediated viral infection. J Virol 2004, 78:1448-1455.

44. Jahan S, Khaliq S, ljaz B, Ahmad W, Hassan S: Role of HCV Core gene of genotype 1a and 3a and host gene Cox-2 in HCV-induced pathogenesis. Virol J 2011, 8:155.

45. Khaliq S, Jahan S, ljaz B, Ahmad W, Asad S, Pervaiz A, Samreen B, Khan M, Hassan S: Inhibition of core gene of HCV 3a genotype using synthetic and vector derived siRNAs. Virol I 2010, 7:318.

46. Henry SD, van der WP, Metselaar HJ, Tilanus HW, Scholte BJ, van der Laan $\mathrm{L}$ : Simultaneous targeting of HCV replication and viral binding with a single lentiviral vector containing multiple RNA interference expression cassettes. Mol Ther 2006, 14:485-493.

doi:10.1186/1743-422X-8-295

Cite this article as: Jahan et al:: Effect of combined siRNA of HCV E2 gene and HCV receptors against HCV. Virology Journal 2011 8:295

\section{Submit your next manuscript to BioMed Central and take full advantage of:}

- Convenient online submission

- Thorough peer review

- No space constraints or color figure charges

- Immediate publication on acceptance

- Inclusion in PubMed, CAS, Scopus and Google Scholar

- Research which is freely available for redistribution 